DOI https://doi.org/10.18551/rjoas.2017-08.21

\title{
THE INFLUENCE OF PRODUCT AND COMPANY IMAGE ON SAVING DECISION THROUGH TRUST VARIABLE AT THE PEOPLE'S CREDIT BANK EKA BUMI ARTHA IN METRO CITY
}

\author{
Suharto*, Suhada Bambang \\ Management Study Program Faculty of Economics, University of Muhammadiyah Metro, \\ Indonesia \\ *E-mail: hartoumm@gmail.com
}

\begin{abstract}
This research uses product image, company image, trust, and saving decision variables. Data used in this research is primary data collected using explanatory survey method with the total population of 14,175 customers. The sample is 150 customer respondents. The instrument used in this research is a Likert scale at the Office of People's Credit Bank Eka Bumi Artha Metro. Testing of requirements instrument includes validity and reliability testing. Meanwhile, normality, homogeneity, linearity, and significance of regression testing are used in order to test the requirements analysis. Data analysis uses Structural Equation Modeling (SEM). The research result found that the product image has a positive effect on trust, the company image does not have direct postifive effect on the trust, product image has direct postifive effect on saving decision, the company image does not have direct postifive effect on the saving decision and the trust has direct postifive effect on the saving decision.
\end{abstract}

\section{KEY WORDS}

Product image, company image, trust, saving decision.

The measurement of the concept of customer saving decision in banking industry often becomes the topic of conversation for banking observer sector (Nilton Porto and J. Michael Collins, 2017). Bank can be regarded as one of the financial institutions that play a major role in building the economy of a country. The more developed the banking industry is the better the economic growth of the country. As stated by (Michal Bialek and Wim De Neys, 2017), that Bank as a financial institution serves to collect and distribute the fund to the community in order to improve the equity, economic growth and national stability for the improvement of community welfare. Thus, the bank can be the facilitator to collect and distribute fund to the community effectively and efficiently for the improvement of standard of living of the community (Triandaru, Sigit dan Totok Budisantoso, 2009).

The development of the banking industry will lead to a competition between banks to obtain customers. Evey bank will need a strategy in order to encourage the customers to save their fund in that bank. The customer is the major driver in the banking industry (Akos Nagy et al., 2014). A bank needs to understand why customers choose certain bank for their transaction and saving service. By understanding the character of the customers, a bank can determine the product development strategy and bank service according to each characteristic of the customer. Thus, one of the fundamental factors of a bank is the willingness from the management in order to obtain more customers (Asto Subroto, 2009).

There are several reasons as the consideration for the customer to be a customer of a bank. One of the reasons is the existence of product variance offered by the bank (Fabio Caldieraro, 2016). What has been perceived by the customer against a product, including product attributes, the benefit for the customer, the use of the product and the safety guarantee.

The image of the bank is another factor that can determine the saving decision when selecting the bank. The bank image can give a larger portion to influence the saving decision when selecting a bank Robert Azuayi. (2016). A good company image that attached to customer's mind will increase the customer satisfaction (Michael R. Solomon et al., 1992). The image describes the overall impression made by the public about a company and its 
product. Awareness and image of a product and service reputation will influence the customer's decision to buy in order to improve its selling (Seita M. Almandeel, 2017). Based on other expert's opinion, a good image showed by the bank to its customer through the reputation and product can give better response and higher trust from the customer against the banking products and it can generate customer's satisfaction (Govers, P.C.M. and J.P.L. Schoormans, 2005).

A positive image of a company or product in community's mind will encourage the customer's interest to save their fund in that bank (Yi Zhang, 2015; Suharto, 2016). There are so many types of savings offered by other banks, thus the management should be able to offer a saving type equipped with a number of attributes that can stimulate the community's interest to invest their money in the bank. If the company can provide a product with the attributes in accordance with the customer's needs and desires, the company will be able to encourage the customer to make the purchasing decision (Methaq Ahmed Sallam, 2016). The community's trust against the bank can be the crown of the company and they have to keep the reputation. The reason is that trust can support the banking industry's growth and development to be a larger and healthier industry.

A positive product image of a bank in the customer's mind will give more advantage to the bank. It can help to build the customer's trust against the product. The reason is that the customer tends to be more aware and more careful against a product they don't know very well. A good quality of a product will be embedded in the customer's mind when they make repurchasing, giving the recommendation to other people, or to influence other people or their family members when these people need to make a purchasing decision.

Banking image is the customer's perception of the overall component in the banking company. For example, the quality of the service, the product quality, responsiveness and so on. The company image can be created through the customer's trust against the bank. A positive company image will encourage the confidence of the customer to use the product of the bank. The consumer's trust is built based on careful consideration, through complete information when a customer will make a purchase and take the decision to make the purchase.

A well-formed product image will give positive effect for the company, which is to convince the customer to get consistent quality when buying a banking product and will always improve the customer's motivation to save their fund in that bank. The quality and good perception based on the customer's point of view against the banking product will create and build satisfaction after the transaction with the company.

The information about a bank is required for the prospective customer, either from the bank itself or from other people experience before deciding to save in a bank. A positive image of the customers through their experience in using their banking service will encourage them to tell that they have good experience to relatives and other people. Thus, encouraging new customer's decision to use the services, to save or keep their fund in that bank. A good image of a company will create the new experience that can be obtained while doing the transaction with other company.

Trust given by the customer and prospective customer on its product is one of the important factors in attracting the customer's interest and keeping the long term relationship between the members of the company. Trust is a descriptive owned by someone against something. The stronger the community's trust against the bank, the stronger the interest and decision of the community to keep their fund in that bank. Strong trust, which consumers acquire through stages and processes that take a long time, will create positive decisions, either decision made by their relative, family members or community.

Based on the background and conceptual framework, the research aims to test the hypothesis about the direct influence of product image against the trust, direct influence of banking image against the trust, direct influence of product image against the saving decision, direct influence of the company image against the saving decision, and direct influence of trust against the saving decision. 


\section{METHODS OF RESEARCH}

The conducted research approach is quantitative with survey method. The constellation in this research uses product image as an exogenous variable, banking image as the exogenous variable, trust as the endogenous variable, and costumers saving decision as the endogenous variable. The target population is all of the customers of People's Credit Bank in Metro City. The sample uses the formula (Slovin, 2013) with 150 respondents.

The instrument used in this study is multiple choice with 5 alternative options and using Likert scale model for product image, banking image, trust, and costumers saving decision variables. The instrument preparation steps include the development of dimension and indicator, instrument preparation, validity and reliability testing, instrument revision, finalization, and data collection.

Instrument validity testing uses biserial correlation, and reliability testing uses the consistency of the respondent. The scale of the product image, company image, trust, and saving decision, is tested its validity using "Product Moment" coefficient and its reliability testing using "Cronbach's Alpha" coefficient (Ghozali, 2011).

Analysis data technique includes descriptive statistical analysis and inflation statistics. The requirements analysis test uses normality, homogeneity, linearity, and significance of regression testing. Multivariate statistics use Structural Equation Modeling analysis.

\section{RESULTS OF STUDY}

Requirements Analysis:

Prior to the data analysis, requirements analysis is needed as follows.

Requirements Analysis Test of Data Normality. Normality test aims to see whether regression model of dependent variable (bound) and independent variable (free) have a contribution or not, normality test is conducted to see if data distribution is normal or not.

Table 1 - Requirements Analysis Test of Data Normality

\begin{tabular}{|c|c|c|c|c|c|}
\hline No. & Estimated Error of Regression & $\mathrm{L}_{\text {count }}$ & $\mathrm{L}_{\text {table }}$ & Decision & Conclusion \\
\hline 1 & $\mathrm{Y}_{1}$ over $\mathrm{X}_{1}$ & 0.064 & 0.072 & $\mathrm{H}_{0}$ accepted & Normal \\
\hline 2 & $\mathrm{Y}_{1}$ over $\mathrm{X}_{2}$ & 0.055 & 0.072 & $\mathrm{H}_{0}$ accepted & Normal \\
\hline 3 & $\mathrm{Y}_{2}$ over $\mathrm{X}_{1}$ & 0.091 & 0.072 & $\mathrm{H}_{0}$ rejected & Not Normal \\
\hline 4 & $\mathrm{Y}_{2}$ over $\mathrm{X}_{2}$ & 0.079 & 0.072 & $\mathrm{H}_{0}$ rejected & Not Normal \\
\hline 5 & $\mathrm{Y}_{2}$ over $\mathrm{Y}_{1}$ & 0.052 & 0.072 & $\mathrm{H}_{0}$ accepted & Normal \\
\hline
\end{tabular}

Requirements Analysis Test of Homogeneity. The result of this test is used to determine the relationship between variables, with the requirement that each variable must have a homogeneous relationship.

Table 2 - Requirements Analysis Test of Homogeneity

\begin{tabular}{|c|c|c|c|c|}
\hline No. & Homogenitas & $\mathrm{X}_{\text {count }}$ & $\mathrm{X}_{\text {table }}$ & Conclusion \\
\hline 1 & $\mathrm{Y}_{1}$ over $\mathrm{X}_{1}$ & 19.334 & 149.885 & Homogeneous \\
\hline 2 & $\mathrm{Y}_{1}$ over $\mathrm{X}_{2}$ & 13.362 & 146.567 & Homogeneous \\
\hline 3 & $\mathrm{Y}_{2}$ over $\mathrm{X}_{1}$ & 32.399 & 149.885 & Homogeneous \\
\hline 4 & $\mathrm{Y}_{2}$ over $\mathrm{X}_{2}$ & 20.998 & 146.567 & Homogeneous \\
\hline 5 & $\mathrm{Y}_{2}$ over $\mathrm{Y}_{1}$ & 48.799 & 143.246 & Homogeneous \\
\hline
\end{tabular}

Requirements Analysis Test of Linearity and Significance of regression. The result of this test is used to determine the relationship between variables, with the requirement that each variable should have a linear relationship and significance of regression. 
Table 3 - Summary of Requirements Analysis Test of Linearity and Significance of regression

\begin{tabular}{|c|c|c|c|c|c|c|}
\hline \multirow{2}{*}{ Variable } & \multicolumn{2}{|c|}{ Sig. Regresi } & \multirow{2}{*}{ The significance of regression } & \multicolumn{2}{|c|}{ Lin. Regression } & \multirow{2}{*}{ Regression Linearity } \\
\cline { 2 - 3 } & $\mathrm{F}_{\text {count }}$ & $\mathrm{f}_{\text {table }}$ & & $\mathrm{F}_{\text {count }}$ & $\mathrm{f}_{\text {table }}$ & \\
\hline $\mathrm{Y}_{1}$ over $\mathrm{X}_{1}$ & 137.76 & 2.12 & Regression is significant & 0.03 & 2.12 & Linear regression \\
\hline $\mathrm{Y}_{1}$ over $\mathrm{X}_{2}$ & 1.08 & 2.12 & Regression is not significant & 0.05 & 2.12 & Linear regression \\
\hline $\mathrm{Y}_{2}$ over $\mathrm{X}_{1}$ & 195.97 & 2.12 & Regression is significant & 0.04 & 2.12 & Linear regression \\
\hline $\mathrm{Y}_{2}$ over $\mathrm{X}_{2}$ & 0.18 & 2.12 & Regression is not significant & 0.08 & 2.12 & Linear regression \\
\hline $\mathrm{Y}_{2}$ over $\mathrm{Y}_{1}$ & 178.05 & 2.12 & Regression is significant & 0.08 & 2.12 & Linear regression \\
\hline
\end{tabular}

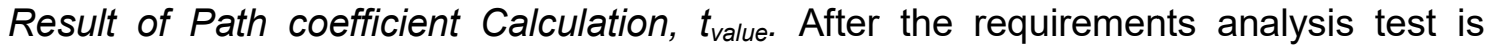
conducted, calculation and testing of each path coefficient as shown in the following table should be done:

Table 4 - Summary of Result of Path Coefficient

\begin{tabular}{|c|c|c|c|c|c|}
\hline \multirow{2}{*}{ No. } & \multirow{2}{*}{ Variable } & \multicolumn{2}{|c|}{ Path Coefficient $(\beta)$} & \multirow{2}{*}{ Decision } & \multirow{2}{*}{ Conclusion } \\
\cline { 3 - 5 } & & SLF $^{*}$ & $\mathrm{~T}_{\text {count }}$ & & \\
\hline 1 & $\mathrm{Y}_{1}$ over $\mathrm{X}_{1}$ & 0.70 & 8.16 & $\mathrm{H}_{0}$ rejected & Significant \\
\hline 2 & $\mathrm{Y}_{1}$ over $\mathrm{X}_{2}$ & -0.07 & -0.95 & $\mathrm{H}_{0}$ accepted & Not Significant \\
\hline 3 & $\mathrm{Y}_{2}$ over $\mathrm{X}_{1}$ & 0.35 & 3.33 & $\mathrm{H}_{0}$ rejected & Significant \\
\hline 4 & $\mathrm{Y}_{2}$ over $\mathrm{X}_{2}$ & 0.04 & 0.59 & $\mathrm{H}_{0}$ accepted & Not Significant \\
\hline 5 & $\mathrm{Y}_{2}$ over $\mathrm{Y}_{1}$ & 0.52 & 4.39 & $\mathrm{H}_{0}$ rejected & Significant \\
\hline
\end{tabular}

*Standardized Loading Factor.

Path Coefficient of Sub-Structure 1:

Analysis model of path coefficient sub-structure 1 is expressed in equation $Y_{1}=\beta_{31} X_{1}+$ $\beta_{32} X_{2}+\varepsilon_{1}$. This testing will provide decision-making of hypotheses testing 1 , and 2 .

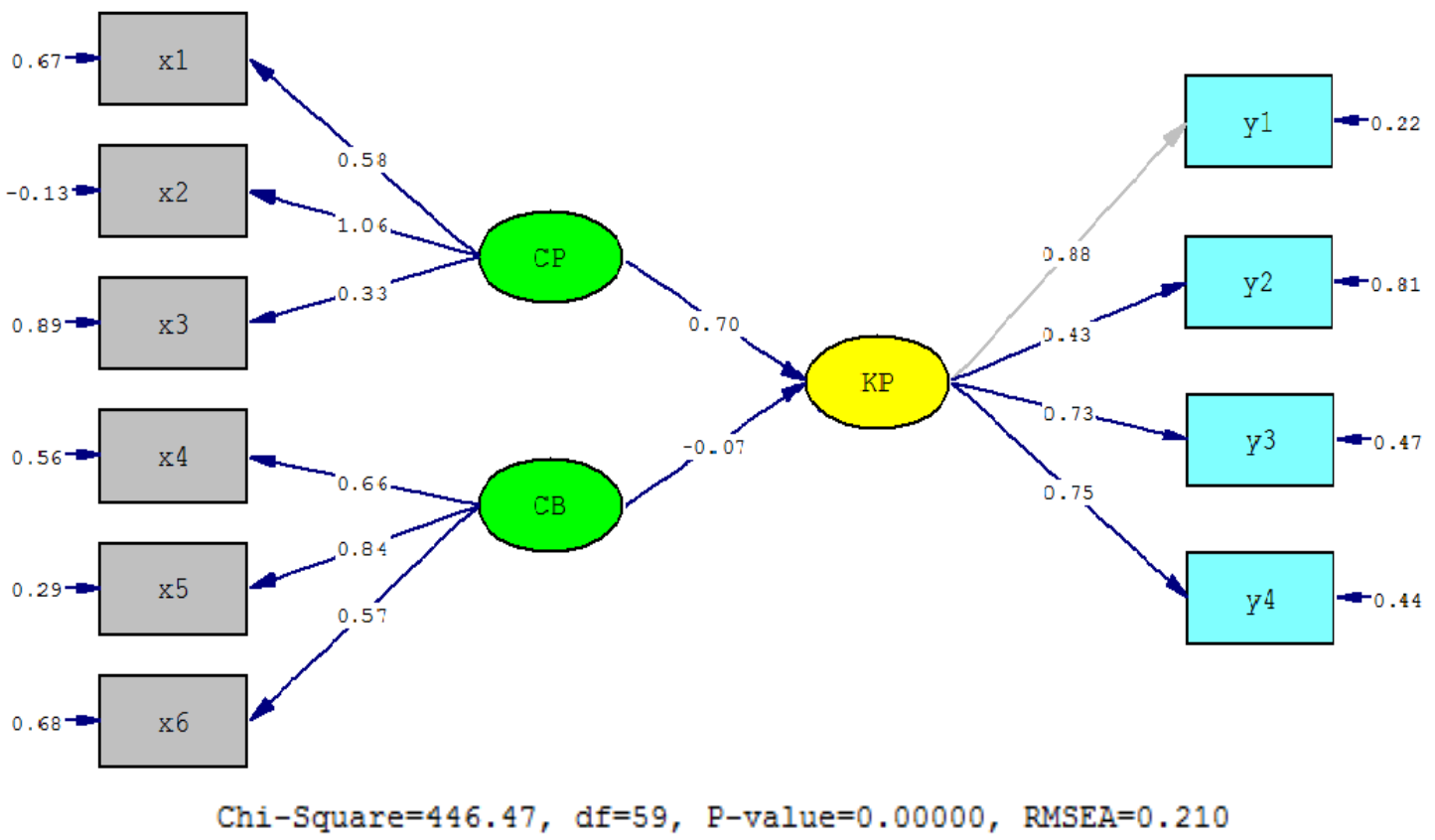

Figure 1 - Path Coefficient of Sub-Structure 1

The testing of sub-structure 1 found that path coefficient $\left(\beta_{31}\right)$ of 0.70 and the value of $t_{\text {count }}=8.16>t_{\text {table }(0.05: 150)}=1.97$ means that $H_{0}$ is rejected and path coefficient $\beta_{31}$ is significant. It shows that product image has direct positive effect on trust. The path coefficient $\left(\beta_{32}\right)$ of -0.07 and the value of $t_{\text {count }}=-0.95<t_{\text {table }(0,05: 150)}=1.97$ means that $H_{0}$ is accepted and path coefficient $\left(\beta_{32}\right)$ is not significants. It shows that banking image does not have direct potive effect on trust. 
Path Coefficient Sub-Structure 2:

Analysis model of path coefficient sub-structure 2 is expressed in equation $Y_{2}=\beta_{41} X_{1}+$ $\beta_{42} X_{2}+\beta_{43} Y_{2}+\varepsilon_{2}$. This testing will provide decision-making of hypotheses testing 3 , 4 , and 5 .

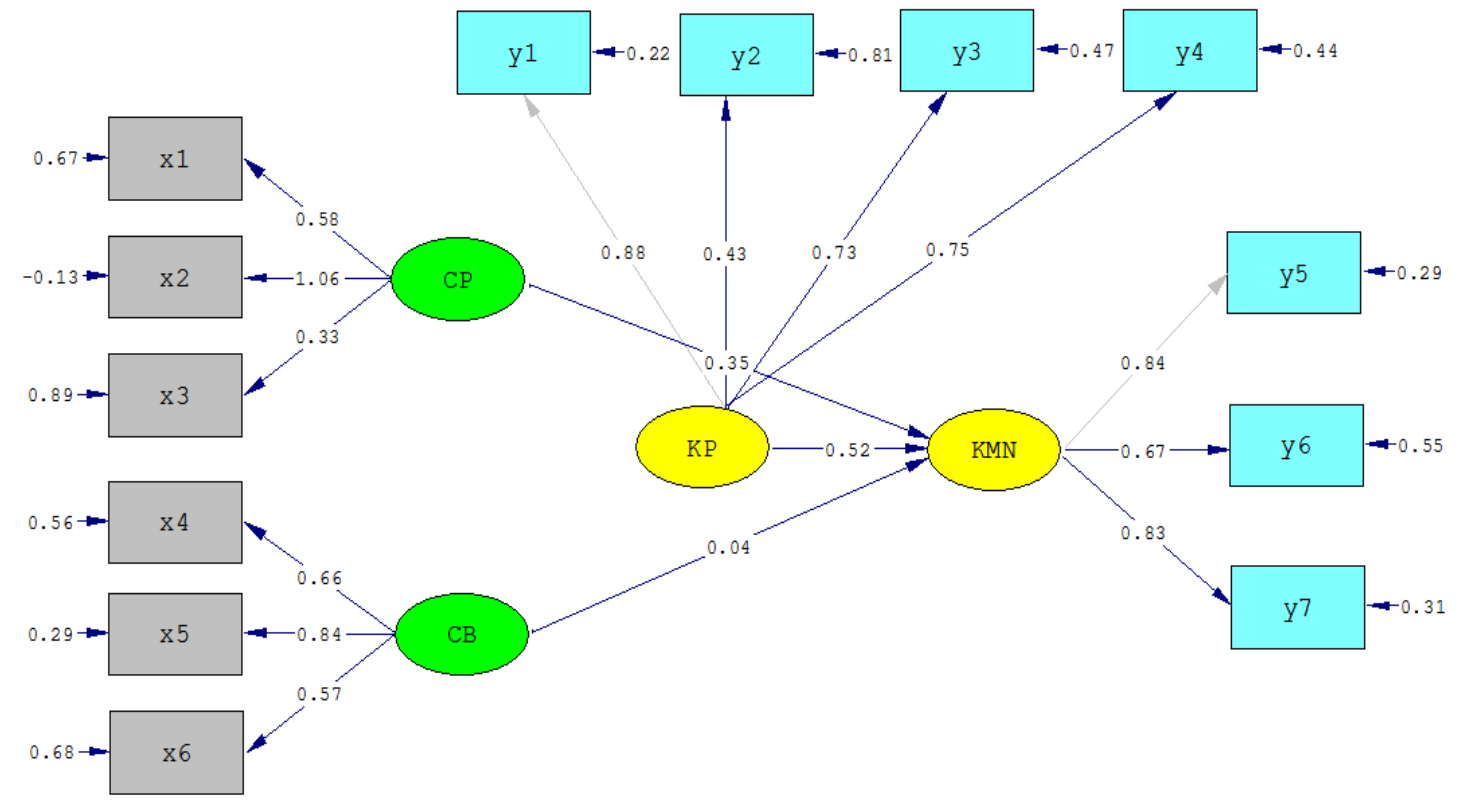

Chi-Square $=446.47, \mathrm{df}=59, \mathrm{P}-\mathrm{value}=0.00000, \mathrm{RMSEA}=0.210$

Figure 2 - Path Coefficient of Sub-Structure 2

Based on the sub-structure 2 testing, the path coefficient $\left(\beta_{41}\right)$ of 0.35 and the value of $t_{\text {count }}=3.22>t_{\text {table(0.05: } 150)}=1.97$ means that $H_{0}$ is rejected and path coefficient $\left(\beta_{41}\right)$ is significant. It means that product image has positive direct effect on the saving decision. Path coefficient $\left(\beta_{42}\right)$ of 0.04 and the value of $t_{\text {count }}=0.59<t_{\text {table(0.05: 150) }}=1.97$ means that $H_{0}$ is accepted and line coefficient $\left(\beta_{42}\right)$ is not significant. Thus, the banking image has no positive direct effect on the saving decision. Path coefficient of $\left(\beta_{43}\right)$ of 0.52 and the value of $t_{\text {count }}=$ $4.39>t_{\text {table(0.05: 150) }}=1.97$ means that $H_{0}$ is accepted and path coefficient $\left(\beta_{43}\right)$ is significant. Thus, trust has direct postifive influence on saving decision.

The calculation of path coefficient and t-value for decided hypothesis testing shows that not all of five path coefficient are sig, $<0.05$ and $t$-value $>1.97$. Thus, two lines that are not significant and three lines are significant.

Path Diagram of standardized solution. Overall the path diagram of standardized solution on each variable can be described as follows in Figure 3.

Based on figure 3 (Path Diagram of Standardized Solution), other than direct influence, there is total and indirect influence between exogenous variables $(X)$ and endogenous variables $(Y)$. Based on the output lisrel on standardized total effect shows that: (1) the value of total effect of product image $\left(X_{1}\right)$, banking image $\left(X_{2}\right)$, and trust $\left(Y_{1}\right)$ against the saving decision $\left(Y_{2}\right)$ is the same as the value of direct effect on each variable because they are not mediated by intervening variable, (2) the value of total effect of product image variable $\left(X_{1}\right)$, and banking image $\left(X_{2}\right)$ against trust $\left(Y_{1}\right)$ is the same with the value of direct effect on each variable because they are not mediated by intervening variable, (3) indirect effect of product image variable $\left(\mathrm{X}_{1}\right)$ against the saving decision of deposito customer $\left(\mathrm{Y}_{2}\right)$ by $0.70 \times 0.52=$ 0.364 , because of the variable intervening in the form of trust $\left(Y_{1}\right)$ by 0.52 . Meanwhile, the total effect is $0.35+0.364=0.714$ and (4) the indirect effect of company image variable $\left(\mathrm{X}_{2}\right)$ against the saving decision of deposito customer $\left(\mathrm{Y}_{2}\right)$ by $-0.07 \times 0.52=-0.27$ because of intervening variable in the form of trust $\left(\mathrm{Y}_{1}\right)$ by 0.52 , the total effect is $0.04-027=0.004$. 


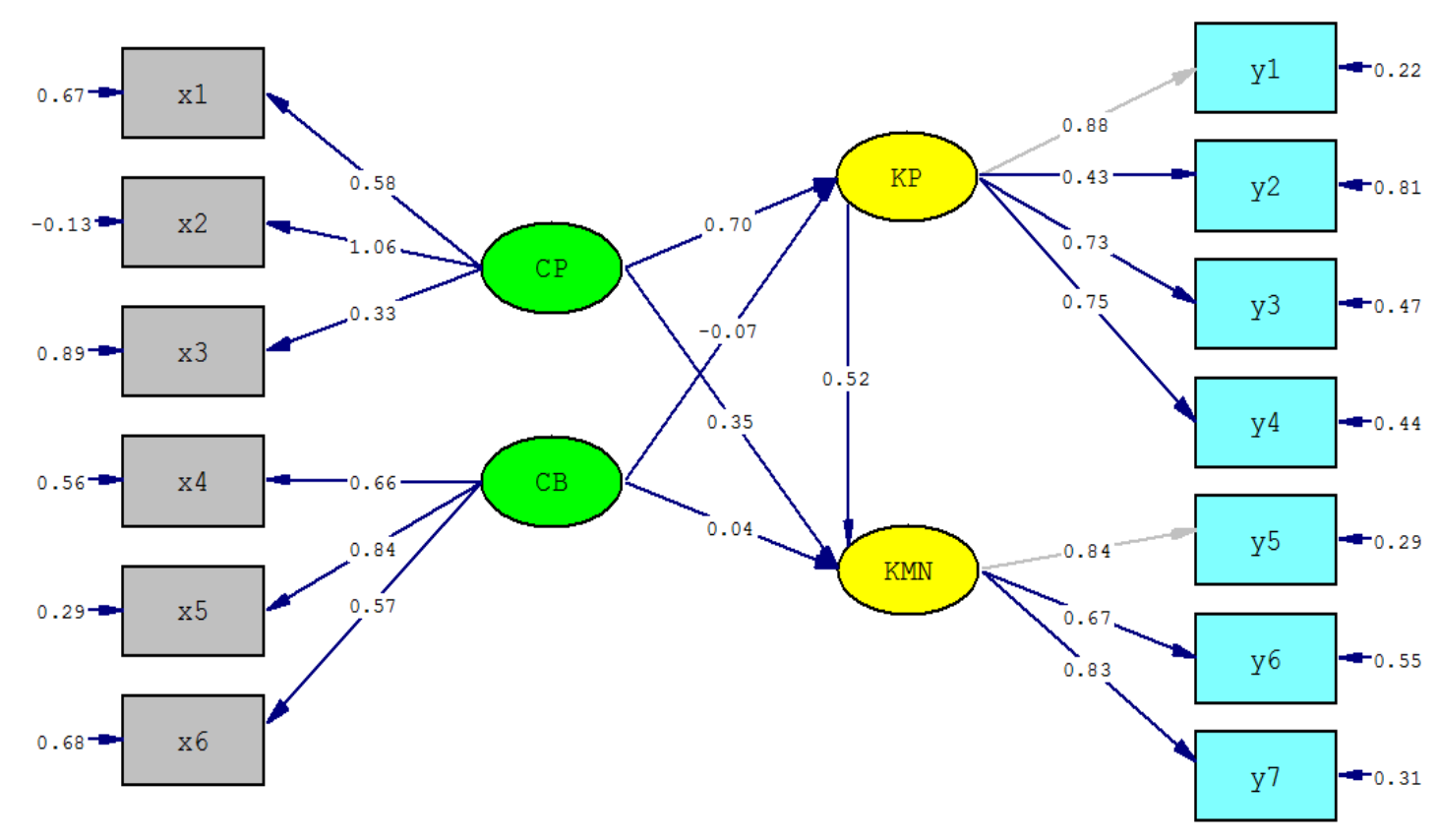

Chi-Square $=446.47, \mathrm{df}=59, \mathrm{P}-\mathrm{value}=0.00000, \mathrm{RMSEA}=0.210$

Figure 3 - Path Diagram of Standardized Solution

The above explanation of the total effect of exogenous variable $(X)$ against the endogenous variable $(Y)$ shows that variable $X_{1}$ has positive effect on $Y_{2}$ because of the existence of intervening (mediation) variable $Y_{1}$ has a greater value of influence compared to variables not mediated by another variable. Meanwhile, variable $X_{2}$ has no positive effect against $Y_{2}$ because of the existence of intervening (mediation) variable $Y_{1}$ that has smaller value of influence compared to variables not mediated by another variable. In other words, product image, banking image, and trust do not jointly influence the costumers saving decision because only product image $\left(X_{1}\right)$ that has a greater value of influence comparing to only one variable $(X)$ that affect the costumers saving decision. It also occurs in the trust variable, product image and banking product do not jointly influence the trust because only one variable $(X)$ that influences trust.

\section{DISCUSSION OF RESULTS}

The Influence of Product image against Trust. The research result found that product image has positive effect on trust. It shows that product of a bank can fulfill the customer's needs, be useful, and in accordance with the customer's expectation. Furthermore, product image also gives the good impression on the community's mind and can ensure them to trust the bank more.

The quality of the banking products that are in accordance with the customer's expectation and has an impressive attribute on the customer's mind. It is expected to increase the customer's trust to keep their fund in the bank.

This finding does not match with the research conducted by (Maliyah, Siti, 2015; Gordius Ago et al., 2015). They state that product image has significant influence on the trust.

Company Image Has Influence on Trust. The research result shows that banking image does not directly influence the trust. It shows that good image of the bank, such as having a social responsibility, having an identity and satisfying performance and service, do not foster the trust of the customer and community.

The finding is incompatible with the research conducted by (Aprilia Irfa'i, 2016; Methaq Ahmed Sallam, 2016) they state that banking image has a significant influence on the trust. 
Product Image Has Influence on Saving Decision. The research result found that product image has positive direct effect against saving decision. It shows that positive product image in the customer's mind, a product that can fulfill the customer's needs, useful banking product, and in accordance with the customer's needs, can influence the costumers saving decision.

The costumers saving decision is influenced by the product image, customer prefer to choose a product with the positive product image. Therefore, management should improve the quality of product owned. They have to pay attention to the product attributes tailored to the needs and expectation of the customers. The higher the image of a product, the better the significant influence on costumer saving decision.

This finding is in accordance with the research conducted by (Pratiwi, Made Suci dkk., 2014; H. Jessie Chen-Yu and Doris H. Kincade. 1996) they state that product image has significant influence on the customers buying decision which is assumed as the costumers saving decision.

Company Image Has Significant Influence on the Saving Decision. The research result suggests that the company image does not have a positive direct effect on the saving decision. This shows that good image of a bank, having a social responsibility, having an identity and satisfying performance and service, do not have a positive effect against saving decision.

This finding is inconsistent with the research conducted by (Aprilia Irfa'i, 2016; Nha Nguyen and Gaston LeBlanc. 1983) they state that the company image has a significant influence on the saving decision.

Trust Has Influence on the Saving Decision. The research result suggests that trust has positive direct effect on the saving decision. This shows that the performance of the employee is in accordance with the expectation. The trust in which the employee has applied necessary working principles, trust in which the company and its employee have a good reputation and trust in which the customer's fund is safe in the company. These things can influence the saving decision.

Trust can emerge because of the sense of belief in the organization that has a quality to bind the customer and find what is being expected. An employee of a certain company is expected to be consistent in conducting the company's activities in accordance with necessary working principles. They have to maintain the company's good image and create a sense of security for the customer in entrusting their fund. Thus, it can improve the customer's trust that can influence the saving decision.

This research result is consistent with the research conducted by Neysa Setyawan dan Edwin, 2014; Nha Nguyen and Gaston LeBlanc. 1983. They state that trust has significant influence on the costumers saving decision.

\section{CONCLUSION AND SUGGESTIONS}

Based on the collected data and the performed test, it can be concluded that:

Product image has a positive effect on trust. It shows that product of a bank can fulfill the customer's needs, be useful, and in accordance with the customer's expectation. Furthermore, image product also gives a good impression in the community's mind and can create senses of belief.

Product image has a positive effect on the costumers saving decision. This explains that positive product image on the customer's mind, a product that can fulfill the customer's needs, useful banking product, and in accordance with the customer's needs can influence the costumers saving decision.

Trust has positive effect on the costumers saving decision. This shows that the performance of the employee is in accordance with the expectation. The trust in which the employee has applied necessary working principles, trust in which the company and its employee have a good reputation and trust in which the customer's fund is safe in the company. These things can influence the saving decision. 
After conducting the research, the author has given several suggestions as follows:

Management should be able to maintain and improve the positive image of the company's product on the customer's mind; the employee has to quickly and accurately explain the products to the customer and by improving the quality of the company's product and its benefit in order to suit the needs of the customer.

Although the banking image has little Influence on the customer's trust, the positive banking image must be maintained and improved.

A positive image of the product on the customer's mind should be maintained all the time because a product with good impression can improve the trust and influence the costumers saving decision.

The banking image that has little influence on the costumers saving decision should be improved in order to maintain the positive image of the bank on the customer's mind.

Trust variable has a greater influence on the costumers saving decision comparing to other variables. Thus, management should be able to keep the commitment in a long term and keep the community's trust to manage their fund. This can be done through good communication, improving the service and applying necessary working principles.

\section{REFERENCES}

1. Akos Nagy, Ildiko Kemeny, Krisztian Szucs, Judit Simon, and Viktor Kiss. (2017). Are opinion leaders more satisfied? Results of a sem model about the relationship between opinion leadership and online customer satisfaction. Society and Economy: Journal of the Corvinus University of Budapest. 39.1 (Mar.) p.141. Word Count: 6383.

2. Aprilia Irfa'i, Farhana. (2016). Pengaruh Kualitas Produk Dan Citra Perusahaan Terhadap KePutusan Nasabah Dalam Menabung Di Bank Jatim Cabang SyariahKediri. Skripsi Fakultas Ekonomi dan Bisnis Ilsam Institut Agama Islam Negeri Tulungagung.

3. Asto Subroto. (2009). Pahami Keinginan Tersembunyi Nasabah. http//www.astosubroto.com/? p=119 (diakses 12 Januari 2017).

4. Fabio Caldieraro. (2016). The role of brand image and product characteristics on firms' entry and OEM decisions. Management Science. 62.11 (Nov.) p.3327. Word Count: 19587. From Gale Educational Database.

5. Ghozali, Imam. (2011). Aplikasi analisis multivanate dengan program SPSS. Semarang: Penerbit UNDIP.

6. Gordius Ago. Suharno. Sri Mintarti. Sugeng Hariyadi. (2015). Effect of Product Quality Perception, Trust, and Brand Image on Generic Drug Buying Decision and Consumer Satisfaction of Hospital Patients in East Kalimantan. European Journal of Business and Management. ISSN 2222-1905 (Paper) ISSN 2222-2839 (Online). Vol.7, No.14, 2015.

7. Govers, P.C.M. and J.P.L. Schoormans. (2005). Product personality and its influence on consumer preference. Journal of Consumer Marketing. 22.4 (Apr.) p.189. Word Count: 44.

8. H. Jessie Chen-Yu and Doris H. Kincade. (1996). Subject Area: Marketing. Effects of product image at three stages of the consumer decision process for apparel products: alternative evaluation, purchase and post-purchase. Journal of Fashion Marketing and Management: An International Journal. ISSN: 1361-2026.

9. Maliyah, Siti. (2015). Pengaruh Citra Merek, Kepercayaan (Trust) Dan Komitmen Terhadap Loyalitas Nasabah Pada PT. Henan Putihrai Asset Management. Jurnal IImiah Manajemen dan Bisnis Volume 1, Nomor 1.

10. Methaq Ahmed Sallam. (2016). Published by Canadian Center of Science and Education. The Impact of Brand Image and Corporate Branding on Consumer's Choice: The Role of Brand Equity. International Journal of Marketing Studies; Vol. 8, No. 1; ISSN. 1918-719X E-ISSN 1918-7203. College of Administrative Sciences, Najran University, Najran, Saudi Arabia.

11. Michael R. Solomon, Richard D. Ashmore, and Laura C. Longo. (1992). The Beauty Match-Up Hypothesis: Congruence Between Types Of Beauty And Product Images In Advertising. Journal of Advertising. 21.4 (Dec.) p.23. Word Count: 7026. 
12. Michal Bialek and Wim De Neys. (2017). Dual Processes And Moral Conflict: Evidence For Deontological Reasoners' Intuitive Utilitarian Sensitivity. Judgment and Decision Making. 12.2 (Mar.) p.148. Word Count: 13951.

13. Neysa Setyawan, Yohana, dan Edwin Japarianto. (2014). Analisa Pengaruh Kepercayaan, Jaminan Rasa Aman dan Aksesbilitas terhadap Minat Menabung Nasabah Bank Danamon di Surabaya. Jurnal Manajemen Pemasaran Petra Vol.2, No.1.

14. Nha Nguyen and Gaston LeBlanc. (1983). The mediating role of corporate image on customers' retention decisions: an investigation in financial services. International Journal of Bank Marketing. ISSN: 0265-2323.

15. Nilton Porto and J. Michael Collins. (2017). Word Count: 4102. (The Role Of Refund Expectations In Savings: Evidence From Volunteer Income Tax Preparation Programs In The United States). Journal of Consumer Affairs. 51.1. p.183.

16. Pratiwi, Made Suci, Suwendra dan Yuliantini. (2014). Pengaruh Citra Perusahaan, Citra Produk dan Citra Pemakai Terhadap Keputusan Pembelian Produk Foremost pada Distro Ruby Soho di Singaraja. Jurnal Manajemen. Volume 2.

17. Robert Azuayi. (2016). Arabian J Bus Manag Review. S2. International Branding Strategies of Global Companies: A Case Study of Sony Ericson. Arabian J Bus Manag Review, an Open Access Journal. Arabian Journal of Business and Management Review. ISSN: 2223-5833.

18. Seita M. Almandeel. (2017). The Mediating Role Of Transformational Leadership Style On Relationship Between Personality Type And Turnover Intention In Saudi Arabian Banking Context. International Journal of Organizational Leadership. (Jan.) p.109. Word Count: 13426.

19. Slovin, C.G. S. (2003). Riset Pemasaran dan Perilaku, Alih Bahasa oleh Umar Husein. Jakarta: PT. Gramedia.

20. Suharto. (2016). Responsiveness, Customer Relationship Management Confidence and Costomer Loyalty. Social and Economic Sciences, Scientific Jurnal Of PPI-UKM. ISSN No. 2356-2536. Vol.3 No. 2.

21. Triandaru, Sigit dan Totok Budisantoso. (2009). Bank dan Lembaga Keuangan Lain. Jakarta: Salemba Empat.

22. Yi Zhang. (2015). Published Online January in SciRes. The Impact of Brand Image on Consumer Behavior: A Literature Review. Department of Marketing, Management School, Jinan University, Guangzhou, China. Open Journal of Business and Management, 3, 58-62. Scientifid Research Publishing. 